\title{
LUKA YANG TERABAIKAN: KAJIAN TENTANG PENGARUH HOSTILE SEXISM DAN KEMARAHAN MORAL TERHADAP MITOS PEMERKOSAAN
}

\author{
THE NEGLECTED HURT : THE EFFECT OF HOSTILE SEXISM AND MORAL OUTRAGE \\ TOWARD MYTH OF RAPE
}

\author{
Oleh : \\ Esa Laili Sindiana ${ }^{1}$ \\ Fathul Lubabin Nuqul ${ }^{2}$
}

\begin{abstract}
Submitted:

28 November 2020

Revision:

26 Mei 2020

Accepted:

10 Agustus 2020

Sexual violence occurs in the form of sexual harassment, rape, pornography and incest. Many victims of sexual violence are women and women are often blamed because women are considered weak, helpless, and not as intelligent as men. This study aims to determine the level of rape culture, hostile sexism, and moral anger. To find out the influence of hostile sexism and moral outrage on rape culture. This study uses a quantitative approach and probability sampling techniques with 260 students from the faculties of psychology, economics, tarbiyah and teaching, sharia, science and technology, and humanities. This study uses the Illinois Rape Myth Acceptance Scale for rape culture, The Ambivalent Sexism Inventory for hostile sexism, and the Deontic Justice Scale for moral outrage. The research used descriptive analysis and multiple linear regression analysis. The result show that hostile sexism has effect toward myth of rape but moral outrage hasn't effect toward myth of rape
\end{abstract}

Keywords: Rape culture; hostile sexism; moral outrage

\begin{abstract}
ABSTRAK
Kekerasan seksual terjadi dalam bentuk pelecehan seksual, pemerkosaan, pornografi, dan inses. Banyak korban kekerasan seksual adalah perempuan. Perempuan sebagai korban sering disalahkan karena dianggap lemah, tidak berdaya, dan tidak secerdas laki-laki. Penelitian ini bertujuan untuk mengetahui tingkat budaya pemerkosaan, seksisme yang bermusuhan, dan kemarahan moral. Untuk mengetahui pengaruh seksisme yang bermusuhan dan kemarahan moral terhadap budaya pemerkosaan. Penelitian ini menggunakan pendekatan kuantitatif dan teknik pengambilan sampel probabilitas dengan 260 mahasiswa dari fakultas psikologi, ekonomi, tarbiyah dan pengajaran, syariah, sains dan teknologi, dan humaniora. Penelitian ini menggunakan SkalaIllinoisRape Myth Acceptance Scaleuntuk mengukur mitos pemerkosaan, The Ambivalent Sexism Inventory untuk hostile sexism, dan Deontic Justice Scale untuk mengukur kemarahan moral. Hasil uji hipotesis menunjukkan ada pengaruh hostile sexism terhadap kepercayaan budaya pemerkosaan, namun kemarahan moral tidak berpengaruh dengan kepercayaan pada budaya pemerkosaan.
\end{abstract}

Kata kunci: Budaya pemerkosaan; Seksisme kebencian; Kemarahan moral

\footnotetext{
${ }^{1}$ Esa Laili Sindiana, Universitas Islam Negeri Maulana Malik Ibrahim Malang, sindilaren56@gmail.com

${ }^{2}$ Fathul Lubabin Nuqul, Universitas Islam Negeri Maulana Malik Ibrahim Malang, lubabin_nuqul@uinmalang.ac.id
} 
ESA LAILI \& FATHUL LUBABIN NUQUL, Luka Yang Terabaikan: Kajian Tentang Pengaruh Hostile Sexism Dan Kemarahan Moral Terhadap Mitos Pemerkosaan

\section{PENDAHULUAN}

Pelecehan seksual sebagai tindakan yang merugikan dan melecehkan kehormatan orang lain. Berdasarkan Badan Pusat Statistik terdapat angka satu dari tiga wanita pada usia 15-64 tahun tercatat pernah mengalami kekerasan seksual maupun fisik di dalam hidupnya. Indonesia terdapat berbagai kasus kekerasan seksual. rata-rata sekitar 35 perempuan menjadi korban kekerasan seksual setiap dua jam sekali di Indonesia. Kasus kekerasan seksual diibaratkan seperti gunung es yang hingga kini masih mengkhawatirkan.

Pelecehan seksual secara umum memiliki tiga aspek yaitu aspek perilaku, situasional, dan legalitas (Mayer, Berchtold \& Oestrich, 1987). Menurut Kelly (Dalam Lubis, 2013) pelecehan seksual memiliki dua golongan yaitu pelecehan seksual dalam bentuk verbal meliputi, ancaman, tatapan penuh nafsu, dan gerakan yang berbau seksual. Bentuk fisik meliputi menyentuh, menyenggol, menepuk, dan meremas. Pelecehan seksual memiliki dua golongan yaitu pelecehan seksual dalam bentuk verbal meliputi, ancaman, tatapan penuh nafsu, dan gerakan yang berbau seksual. Bentuk fisik meliputi menyentuh, menyenggol, menepuk, meremas dan pelecehan seksual dapat terjadi kapan saja dan dimana saja, pada umumnya korban pelecehan seksual banyak terjadi pada wanita namun, laki-laki juga dapat menjadi korban pelecehan seksual (Lubis, 2013)

Banyak korban kekerasan seksual yang enggan melaporkan kasusnya kepada pihak yang berwajib dengan alasan malu, takut dengan keluarga, malu dengan aib jika orang lain tahu, pemahaman bahwa kekerasan yang terjadi karena ulah korban sendiri, dan ketergantungan pada pelaku.( Jamaa, 2014).

Korban pemerkosaan sering disudutkan. Hal ini dikarenakan mitos pemerkosaan yang telah menyebar luas di masyarakat, perempuan dianggap mengundang terjadinya pemerkosaan. Mitos pemerkosaan ada enam, pertama perkosaan terjadi karena nafsu yang tidak dapat dikontron. Dua korban dipaksa melakukan hubungan seksual dengan orang yang tidak ia kenal. Tiga, pemerkosaan hanya terjad pada masyarakat kalangan bawah atau orang miskin. Empat, perempuan diperkosa karena penampilannya yang seksi dan mengundang pemerkosaan. Lima, pemerkosaan terjadi di tempat yang sepi. Enam, perempuan memang ingin diperkosa (Dwiati, 2007)

Menurut Herman (1989) rape culture didefinisikan secara luas sebagai konteks sosial budaya seksualitas laki-laki yang agresif dan erotis dipandang sebagai hubungan seksual yang normal, sehat, dan diinginkan. Buchwald, Fletcher \& Roth, (2005) menyatakan rape culture adalah budaya yang mendorong agresi seksual pria terhadap wanita dan dipandang sebagai suatu hal yang wajar.

Diskriminasi pada gender yang menjadi penyebab kekerasan seksual juga dikenal dengan istilah seksisme yang telah terjadi sejak Gerakan Pembebasan Perempuan (Women's Liberation Movement) tahun 1960. Pada zaman itu tekanan terhadap kaum perempuan telah menyebar luas diseluruh lapisan masyarakat, sehingga menyebabkan masyarakat bersuara tentang paham sexism (Salama, 2013). Menurut pendapat dari Mills (Hermawati, 2018) hostile sexism sama seperti rasisme maupun bentuk bahasa lainnya, hostile sexism terbentuk karena tekanan masyarakat yang besar, ketidak adilan pada kekuasaan, dan terjadilah konflik terhadap posisi tertentu dan hak tertentu. Sexism juga tidak berupa pernyataan yang hanya fokus pada gender, tetapi sexism juga fokus pada hal lain seperti pembaca dan pendengar yang berkontribusi dalam pernyataan sexism, kemudian faktor lain yang menjadi penyebab sexism adalah prasangka bahwa semua aktivitas yang dilakukan perempuan hanyalah cobacoba berbeda dengan aktivitas yang dilakukan oleh laki-laki.

Keadaan yang menyebabkan korban tidak mendapatkan keadilan dari peristiwa kekerasan seksual menjadi pemicu kemarahan moral. Menurut Wakslak, Jost, Tylor, \& Chan (2007) moral outrage adalah semakin besarnya tingkat kemarahan moral maka semakin tinggi tingkat kesadaran akan ketidakadilan sosial. 
Terdapat 174 kasus kekerasan seksual di perguruan tinggi. Kasus tersebut telah tersebar di 29 kota yang berasal dari 79 perguruan tinggi. Mayoritas $88 \%$ terjadi di kampus-kampus Pulau Jawa yaitu, Semarang dan Yogyakarta.Wilayah tersebut merupakan kampus dengan jumlah paling banyak terjadinya kasus kekerasan seksual dan hampir seluruh korbanya mahasiswa. Pelaku kekerasan seksual di kampus sangat beragam mulai dari dosen, mahasiswa, staf, warga di lokasi KKN, dan dokter di klinik kampus. Sebanyak 129 menyatakan pernah dilecehkan, 30 mengalami intimidasi bernuansa seksual, dan 13 menjadi korban pemerkosaan. Separuh dari 179 korban memilih menyimpan permasalahanya sendiri, alasan utamanya ialah takut, dianggap tidak punya bukti, dan khawatir dianggap berlebihan. (Zuhra, 2019).

Data tersebut membuat peneliti melakukan penelitian di lingkungan kampus khususnya pada mahasiswa untuk mengetahui pendapat mahasiswa terkait dengan rape culture. Mahasiswa mempunyai peran penting di area kampus maupun lingkungan masyarakat, mahasiswa sebagai salah satu penyumbang pengetahuan kepada masyarakat di lingkungan sekitar serta menjadi cermin masyarakat di masa depan yang memiliki nilai pendidikan yang luas. Mahasiswa memiliki andil untuk memajukan bangsa dan memberikan perubahan yang lebih baik, maka mahaiswa juga harus kritis menanggapi berbagai fenomena yang terjadi di masyarakat terutama kasus kekerasan seksual. Penelitian ini dilakukan dengan maksud untuk mengetahui pandangan mahasiswa Universitas Islam Negeri Maulana Malik Ibrahim Malang mengenai rape culture di Indonesia. Peneliti ingin mengetahui tingkat rape culture pada mahasiswa dan pengaruhnya antara hostile sexism dan moral outrage terhadap rape culture.

Penelitian yang dilakukan oleh Sills (2016) menyatakan bahwa banyaknya terjadi pelanggaran seksual dilakukan melalui promosi di media sosial dan dilakukan oleh sekelompok remaja putra yang mnyebabkan perhatian publik terhadap kekerasan seksual dan budaya pemerkosaan sangat menonjol terutama di Selandia Baru pada tahun 2014. Tindakan dalam budaya pemerkosaan dengan menyalahkan korban, mengkritik budaya pemerkosaan, dan peradilan pidana yang tidak memadai terkait budaya pemerkosan. Media sosial banyak membicarakan tentang unsur-unsur budaya pemerkosan yaitu menormalkan seksual laki-laki, mempermalukan perempuan, menyalahkan korban kekerasan seksual dengan cara menempatkan mereka dalam sexism yang mengungkapkan kebencian dan ancaman sebagai normalisasi budaya pemerkosaan.

Sills (2016) melanjutkan penelitianya terkait dengan media sosial feminis, tanggapan terhadap budaya pemerkosaan, kesaksian, dan pemberian saran, dan dukungan terhadap korban. Dukungan tersebut dilakukan dengan cara memberikan pendidikan feminis dan ruang interaksi yang aman, dengan memikirkan fungsi sebagai pembinaan kolektif kelompok gender yang terpinggirkan, membekali korban dengan dukungan, pengetahuan, dan alat untuk merespon sebuah peristiwa secara kritis untuk budaya pemerkosaan.

Penelitian yang dilakukan oleh Krishnan (2015) India memiliki kecenderungan untuk melihat kekerasan gender dan kebencian terhadap wanita sebagai ekspresi budaya dan tradisi, dalam sebuah wawancara film documenter 2015 India Doughter yang disutradarai oleh Leslie Udwin dan Mukesh Singh yang merupakan salah satu pria yang dihukum karena pemerkosaan dan pembunuhan di Delhi pada bulan Desember 2012. Membenarkan pemerkosaan dengan alasan bahwa korban telah melampaui batasnya dalam peran gender yang ditentukan oleh moralitas feminism dengan menyalahkan korban.

Tindakan menyalahkan korban mendapatkan banyak kecaman di seluruh dunia sebagai ungkapan budaya yang brutal dan tidak beradap dari kejahatan perkosaan dan kejahatan. Kecenderungan dan kebencian terhadap wanita juga terjadi di bawah tekanan kasta dan wanita yang tertindas karena kemiskinan, perampasan, dan budaya hak istimewa maskulin di India, bahwa kekuasaan dan tekanan kasta yang tinggi telah mendara daging di India. Sexism di India dan rape culture juga disebabkan oleh kapitalisme, banyak wanita yang dipekerjakan 
ESA LAILI \& FATHUL LUBABIN NUQUL, Luka Yang Terabaikan: Kajian Tentang Pengaruh Hostile Sexism Dan Kemarahan Moral Terhadap Mitos Pemerkosaan

tanpa dibayar, tidak mendapatkan tunjangan hak-hak wanita untuk melahirkan, dan kesehatan fisik maupun psikologis. Oleh karena itu di India serentak menganut sexism, budaya membenarkan pemerkosaan dan pengawasan tentang perempuan, sebagai cara mendisiplinkan tenaga kerja perempuan secara kapitalis.

Penelitian oleh Putri (2012) pemberitaan pemerkosaan di Koran Suara Merdeka yang memberikan gambaran kondisi perempuan korban pemerkosaan. Korban pemerkosaan digambarakan dalam pemberitaan dengan kecenderungan menyalahkan korban mempengaruhi cara pandang masyarakat terhadap korban pemerkosaan sebagai sosok yang bertanggung jawab dan pemicu terjadinya pemerkosaan. Stigma tersebut dapat semakin berkembang pesat maupun semakin meluruh dengan penyajian berita. Media memberikan gambaran yang tidak seimbang atas kondisi korban.

Berita merupakan produk dari media masa yang dapat mempengaruhi pola pikir masyarakat. Perempuan identik dengan kekerasan seksual yang biasa dilakukan oleh lakilaki, baik kekerasan secara fisik maupun bentuk kekerasan seksual lainnya, perempuan seringkali dianggap sebagai sosok yang lemah, tertindas, tidak berdaya. Ciri-ciri tersebut dimaknai dalam kehidupan masyarakat di media massa. Penggambaran pada media massa terkait dengan perempuan masih banyak ketidak berpihakan pada perempuan, hal ini terlihat jelas dari bagaimana media memotret tindak kriminal yang terjadi dengan melibatkan perempuan baik sebagai pelaku maupun korban kejahatan. Mayoritas korban perempuan digambarkan tidak seimbang oleh wartawan, dari pemilihan kata-kata, dan diskripsi tentang korban perempuan dalam kasus pemerkosaan cenderung disalahkan atas kejadian yang telah menimpa mereka.

Hasil penelitian yang dilakukan Kurniasari (2011) menunjukkan bahwa sexism juga terjadi di beberapa karya musik seperti pada lirik lagu Surti-Tejo yang terdapat relasi jenis kelamin tidak seimbang antara laki-laki dan perempuan.Perempuan digambarkan sebagai sosok yang setia, dikontrol seksual oleh laki-laki, dan mengurusi hal domestik.Sedangkan laki-laki digambarkan sebagai sosok yang kuat, ditampilkan dengan aura yang baik, dan sebagai penguasa dalam segala hal.

Penelitian yang dilakukan oleh Posel (2005) bahwa kekerasan seksual telah terjadi sejak lama dan menjadi peristiwa yang diselimuti oleh berbagai tatanan kerahasiaan dan keheningan publik. Namun, pada akhir tahun 2002 pembicaraan publik tentang kekerasan seksual dan pemerkosaan tidak ada hentinya dan semakin memperhatinkan dari beragam kesaksian melalui media talkshow, media massa, artikel majalah, surat redaksi, dan bentukbentuk komentar lainnya. Dari beragamnya peredaran berita dan komentar melaui media sosial yang semakin memecahkan kesunyian kekerasan seksual yang menghebohkan publik.

Gelombang kemarahan masyarakat mulai memuncak dengan melakukan aksi demo ke jalan-jalan. Masyarakat menyuarakan kembali hukuman mati bagi pelaku pemerkosaan.Ledakan ini diberikan dengan ancaman seksual laki-laki pada kekerasan seksual korban perempuan. Ledakan kesedihan dan kemarahan masyarakat ini dikarenakan banyaknya kasus pemerkosaan, korban yang dinodai secara seksual hingga murni secara moral, trauma akibat kekerasan fisik dan trauma secara psikologis, serta penemuan pemerkosaan pada bayi korban kekerasan seksual, disini jelas korban pemerkosaan pada bayi yang tidak bersalah, rapuh serta murni dari tindakan pelaku semakin memperparah amarah masyarakat untuk menyuarakan hukuman dan keadilan moral bagi korban pemerkosaan. Situasi pelanggaran moral atas kesalahan perbuatan atau kekacauan dengan kerugian yang terjadi pada korban yang memicu kemarahan moral dengan tujuan untuk mengembalikan keadaan dan keadilan bagi korban yang dirugikan agar kembali kepada keadaan semula tanpa ada pihak yang lemah atau merasa dirugikan.

Berdasarkan paparan diatas makai hipotesis mayor yang dirumuskan dalam penelitian ini adalah terdapat pengaruh antara hostile sexism dan moral outrage terhadap rape culture. 
sedangkan hipotesis minor terdiri dari tiga hipotesis yang pertama, terdapat pengaruh yang signifikan antara rape culture dan hosyile sexism, kedua terdapat pengaruh yang signifikan antara rape culture dan moral outrage, ketiga tidak terdapat pengaruh yang signifikan antara hostile sexism dan moral outrage.

\section{METODE}

Penelitian ini menggunakan metode survey dengan pendekatan kuantitatif korelasional. Pendekatan ini mengunakan data-data angka bergejala ordinal dari respon subjek yang diteliti. Penelitian ini memfokuskan pada rape culture dan hostile sexism sebagai variabel bebes serta moral outrage sebagai variabel terikat.

\section{Instrumen Pengukuran}

Rape Culture menggunakan skala pengukuran Illinois Rape Myth Acceptance Scale (penerimaan mitos pemerkosaan) yang dikembangkan oleh Payne, Kimberly, \& Louise (1999) yang terdiri dari 25 item. Skala ini memiliki tiga aspek yaitu, sex role stereotyping (stereotip peran jenis kelamin), adversarial sexual beliefs (penerimaan terhadap permusuhan seksual), dan acceptance of interpersonal violence (penerimaan terhadap kekerasan interpersonal). Pada penelitian ini temukan nilai reliabilitas alpha cronbach dari skala Illinois Rape Myth Acceptance Scale sebesar 0.876

Hostile sexism dalam penelitian ini menggunakan skala The Ambivalent Sexism Inventory yang dikembangkan oleh Glick dan Fiske (1996) yang terdiri dari 10 item. Skala ini terdiri dari tiga aspek, yaitu, dominative paternalism (keyakinan bahwa perempuan adalah individu yang lemah dan tidak memiliki kemampuan secara penuh dalam menjalankan tanggung jawabnya), perbedaan gender kompetitif (keyakinan bahwa justifikasi sosial mengarah pada kekuatan struktur pria dan wanita dianggap lebih lemah), dan hostilitas heteroseksual (keintiman dalam hubungan seksual antara perempuan dan laki-laki terkadang membawa ancaman kekerasan). Pada penelitian ini temukan nilai reliabilitas alpha cronbach dari skala The Ambivalent Sexism Inventory sebesar 0.822

Moral outrage menggunakan skala Deontic Justice Scale (DJS) yang dikembangkan oleh Beugre (2012) yang terdiri dari 23 item. Skala ini memiliki tiga aspek antara lain, moral obligation (Berkeyakinan bahwa seseorang memiliki kewajiban moral untuk bertindak adil pada orang lain), moral accountability (berkeyakinan bahwa seseorang perlu dimintai pertanggung jawaban atas kesalahannya), dan moral outrage (terdapat reaksi emosional berupa marah, sedih, kecewa ketika melihat orang lain tidak diperlakukan secara tidak adil dan memiliki keinginan untuk memberikan hukuman bagi pelaku) Model penskoran ketiga variabel tersebut menggunakan skala likert dengan empat pilihan jawaban yaitu sangat setuju, setuju, tidak setuju, dan sangat tidak setuju. Pada penelitian ini temukan nilai reliabilitas alpha cronbach dari skala Deontic Justice Scale sebesar 0.911

\section{Subjek Penelitian}

Penelitian ini melibatkan subjek penelitian mahasiswa Universitas Islam Negeri Maulana Malik Ibrahim Malang. Total populasi dalam penelitian ini sebanyak 15.426 mahasiswa maka, pengambilan sampel berdasarkan tabel Krejcie Morgan dengan confidence 90\% sebanyak 260 mahasiswa, dari semester satu sampai semester tujuh yang terdiri dari mahasiswa perempuan sebanyak 130 dan mahasiswa laki-laki sebanyak 130 dengan rentan usia 17 sampai 25 tahun, yang terdiri dari fakultas psikologi, fakultas ekonomi, fakultas humaniora, fakultas FITK, fakultas sains dan teknologi, dan fakultas syari'ah. Teknik 
ESA LAILI \& FATHUL LUBABIN NUQUL, Luka Yang Terabaikan: Kajian Tentang Pengaruh Hostile Sexism Dan Kemarahan Moral Terhadap Mitos Pemerkosaan

probability sampling dalam penelitian ini menggunakan sample random sampling yang memberikan peluang bagi setiap anggota populasi untuk dipilih menjadi anggota sampel tanpa kriteria yang menjadi batasan dalam penelitian ini. Instrumen pengumpulan data menggunakan uji validitas dan reliabilitas sedangkan metode analisis data menggunakan analisis deskripsi dan analisis regresi linier berganda.

\section{HASIL DAN PEMBAHASAN}

Deskripsi variabel penelitian dilakukan dengan tujuan untuk memaparkan data hasil penelitian berdasarkan masing-masing variabel penelitian. Pada penelitian ini, peneliti memaparkan hasil skor hipotetik dan empirik serta deskripsi kategori data.

Tabel 1.

Hasil Uji Deskripsi

\begin{tabular}{lllllll}
\hline & \multicolumn{3}{c}{ Hipotetik } & & Empirik \\
\hline Variabel & Maks & Min & Mean & Maks & Min & Mean \\
\hline Rape Culture & 100 & 25 & 73 & 80 & 30 & 58,16 \\
\hline Hostile Sexism & 40 & 10 & 25 & 40 & 11 & 26,84 \\
\hline Moral Outrage & 36 & 9 & 23 & 36 & 15 & 27,62 \\
\hline
\end{tabular}

Berdasarkan tabel 1 diketahui bahwa besaran skor rape culture mean hipotetik lebih tinggi daripada mean empirik artinya, level rape culture mahasasiswa cenderung rendah karena dibawah rata-rata dari skala yang digunakan. Pengukuran pada hostile sexism jika dibandingkan antara mean hipotetik dengan mean empirik maka, mean empirik lebih besar daripada mean hipotetik artinya level hostile sexism mahasiswa cenderung tinggi. Pengukuran pada moral outrage jika dibandingkan antara mean hipotetik dengan mean empirik maka, lebih besar mean empirik artinya, level moral outrage mahasiswa cenderung tinggi.Kategorisasi tingkat rape culture dapat dijelaskan dalam tabel dibawah ini:

Tabel 2.

Kategorisasi Tingkat Rape Culture

\begin{tabular}{|c|c|c|c|}
\hline Kategori & Kriteria & Frekuensi & Presentase \\
\hline Tinggi & $76-100$ & 46 & $17,7 \%$ \\
\hline Sedang & $50-75$ & 206 & $79,2 \%$ \\
\hline Rendah & $25-49$ & 8 & $3,1 \%$ \\
\hline \multicolumn{2}{|c|}{ Total } & 260 & $100 \%$ \\
\hline
\end{tabular}

Berdasarkan tabel 2, hal ini menunjukkan bahwa tingkat rape culture mahasiswa Univerisas Islam Negeri Maulana Malik Ibrahim Malang paling banyak terdapat pada kategori sedang dengan tingkat presentase $79,2 \%$ artinya, mahasiswa cenderung tidak memberikan komentar negatif pada korban perempuan, tidak menyalahkan korban perempuan, tidak menormalkan agresi seksual laki-laki, dan mampu untuk memberikan dukungan sosial bagi korban pemerkosaan.

Kategorisasi hostile sexism dapat dijelaskan dalam tabel dibawah ini: 
Tabel 3.

Kategorisasi Tingkat Hostile Sexism

\begin{tabular}{llll}
\hline Kategori & Kriteria & Frekuensi & Presentase \\
\hline Tinggi & $31-40$ & 15 & $5,8 \%$ \\
\hline Sedang & $20-30$ & 190 & $73,1 \%$ \\
\hline Rendah & $10-19$ & 55 & $21,2 \%$ \\
\hline & & $\mathbf{2 6 0}$ & $\mathbf{1 0 0} \%$ \\
\hline
\end{tabular}

Berdasarkan tabel 3, dapat diketahui bahwa tingkat hostile sexism mahasiswa Universitas Islam Negeri Maulana Malik Ibrahim Malang terdapat pada kategori sedang dengan tingkat presentase $73,1 \%$ artinya, mahasiswa cenderung tidak memberikan penilaian negatif kepada wanita dan mampu untuk menyeimbangkan antara laki-laki dan perempuan dengan tidak saling mendominasi sehingga tidak terjadi diskriminasi.Kategorisasi tingkat moral outrage dijelaskan dalam tabel dibawah ini:

Tabel 4.

Kategorisasi Tingkat Moral Outrage

\begin{tabular}{|c|c|c|c|}
\hline Kategori & Kriteria & Frekuensi & Presentase \\
\hline Tinggi & $28-36$ & 4 & $1,5 \%$ \\
\hline Sedang & $18-27$ & 130 & $50 \%$ \\
\hline Rendah & $9-17$ & 126 & $48,5 \%$ \\
\hline \multicolumn{2}{|c|}{ Total } & 260 & $100 \%$ \\
\hline
\end{tabular}

Berdasarkan tabel 4, diketahui bahwa tingkat moral outrage mahasiswa Universitas Islam Negeri Maulana Malik Ibrahim Malang paling banyak terdapat pada kategori sedang dengan tingkatpresentase $50 \%$ artinya, mahasiswa cenderung memiliki respon emosional yang stabil dan tidak mudah marah dan tidak pula mengabaikan keadaan oaran lain disekitarnya. mahasiswa Universitas Islam Negeri Maulana Malik Ibrahim Malang cukup mampu untuk mengontrol diri pada peristiwa sekitar yang berhubungan dengan moral.

Pada uji asumsi dilakukan dengan menggunakan random sampling, uji normalitas, uji linieritas, dan uji hipotesis. Pada uji normalitas dalam penelitian ini menggunakan Kolomogorov-Smirnov Testdengan melihat hasil perhitungan pada nilai output Asymp. Sig (2tailed).Jika nilai signifikansi >. 0,05 maka data terdistribusi normal. Jika, nilai signifikansi $<0,0$ maka data tidak terdistribusi normal. Hasil uji normalitas dapat dilihat pada tabel dibawah ini.

Tabel 5.

Hasil Uji Normalitas

\begin{tabular}{llll}
\hline Variabel & K-SZ & Sig. $(\mathbf{p})$ & Status \\
\hline Rape Culture & 719 & 0,680 & Normal \\
\hline Hostile Sexism & 1.005 & 0,265 & Normal \\
\hline Moral Outrage & 1.248 & 0.089 & Normal \\
\hline
\end{tabular}

Berdasarkan tabel 5, mendapatkan hasil bahwavariabel berdistribusi normal (sig > 0,05) dengan nilai K-SZ rape culture sebesar 719, hostile sexism sebesar 1,005, dan moral outrage sebesar 1,248. Hal ini artinya, ketiga skala yang mengukur variabel menghasilkan skor normal, artinya skor tersebut sesuai, tidak terlalutinggi dan tidak terlalu rendah. 
ESA LAILI \& FATHUL LUBABIN NUQUL, Luka Yang Terabaikan: Kajian Tentang Pengaruh Hostile Sexism Dan Kemarahan Moral Terhadap Mitos Pemerkosaan

Perhitungan pada uji linieritas dalam penelitian ini menggunakan program SPSS 16.0 for windows melalui nilai signifikansi outpit SPSS. jika nilai sig < 0,05 maka terdapat hubungan yang linier. Uji linier juga digunakan untuk melihat apakah data berkorelasi secara linier atau tidak.Data yang memiliki korelasi linier menjadi syarat bahwa data dapat dianalisis menggunakan analisis linier berganda. Hasil uji linier dalam penelitian ini sebagai berikut.

Tabel 6.

Hasil Uji Linieritas

\begin{tabular}{lll}
\hline Variabel & Hostile Sexism & Moral Outrage \\
\hline Rape Culture & 0,000 & 0,002 \\
\hline Keterangan & Linier & Linier \\
\hline
\end{tabular}

Berdasarkan tabe 6, diperoleh hasil bahwa adanya hubungan yang linier antara variabel rape culture dan hostile sexism dan moral outrage. Hal ini dibuktikan dengan hasil sig < $0,05)$ artinya, terdapat pengaruh yang signifikan antara variabel rape culture dengan hostile sexism dan moral outrage.

Uji hipotesis dalam penelitian ini untuk mengetahui ada atau tidaknya pengaruh antara hostile sexism dan moral outrage terhadap rape culture pada mahasiswa Universitas Islam Negeri Maulana Malik Ibrahim Malang. Sebagaimana dalam tabel 7 bahwa secara simultan hostile sexism dan moral outrage memiliki pengaruh yang signifikan terhadap rape culture. Hasil koefisien determinan $\left(\mathrm{R}^{2}\right)$ sebesar 0,401 maka, dapat diketahui terdapat pengaruh sebesar 40,1\% hostile sexism dan moral outrage terhadap rape culture. Adapun 59,9\% sisanya dapat dipengaruhi oleh variabel lain yang tidak diteliti dalam penelitian ini. Dari tabel 7 juga di ketahui bahwa secara parsial bahwa hanya Hostile sexism yang berpengaruh pada rape culture, sedangkan moral outrage tidak.

Tabel 7.

Rangkuman Hasil Uji Analsis Regresi

\begin{tabular}{lllll}
\hline Variabel Bebas & Variabel Terikat & F & R2 & Beta \\
\hline Hostile sexism & Rape culture & \multirow{2}{*}{$86,108^{* * *}$} & \multirow{2}{*}{0,401} & $0,624^{* *}$ \\
\hline Moral Outrage & & & 0,033 \\
\hline
\end{tabular}

Keterangan $* *$ signifikan pada $\mathrm{p}<0.01$

Berdasarkan hasil penelitian menunjukkan bahwa rape culture pada mahasiswa Universitas Islam Negeri Maulana Malik Ibrahim Malang dalam kategori sedang dengan prosentase mencapai $79,2 \%$. Artinya mahasiswa cenderung tidak menyalahkan korban pemerkosaan atas terjadinya pemerkosaan. Mahasiswa juga tidak mudah menerima mitos pemerkosaan yang mengangap bahwa perempuan sebagai penyebab pemerkosaan dan ingin diperkosa. Grubb \& Turner (2012) berpendapat bahwa mitos pemerkosaan dapat digunakan sebagai alat bagi pemerkosa untuk membenarkan tindakan kekerasan kepada perempuan dan sebagai dampaknya korban pemerkosaan tidak melaporkan pemerkosaan kepada pihak yang berwajib atau orang terdekat karena merasa bahwa laporannya tidak dipercaya dan akan disalahkan.

Hasil penelitian yang nunjukkan bahwa ada pengaruh hostile sexims dengan rape culture, menguatkan penelitian-penelitian sebelumnya (Chapleau, Oswald, \& Russell, 2008; Poerwandari, Utami \& Primasari, 2019; Kunst, Bailey, Prendergast \& Gundersen, 2019). Poerwandari, Utami \& Primasari, 2019; menegatakan dalam hasil penelitiannya bahwa sexism yang merupakan pandangan inferior pada wanita termasuk keyakinan mengenai 
kurangnya intelegensi dan kompensi pada perempuan (Bonnita, Sarwono, \& Novianti, 2006). Pandangan ini mempengaruhi penerimaan pada mitos pemerkosaan, lebih lanjut Chapleau, Oswald, \& Russell, (2008) mengatakan bahwa hostile sexism yang tinggi mempengaruhi penerimaan pada mitos pemerkosaan baik khususnya pada laki-laki, namun pengaruh ini melemah pada perempuan.

Kunst, Bailey, Prendergast \& Gundersen, (2019), melakukan penelitian pada dua negara (amerika dan norwegia), menemukan bahwa laki-laki dengan dengan sexims tinggi lebih mempunyai penerimaan pada mitos pemerkosaan. Penelitian lain yang dilakukan oleh Hayes, Lorenza dan Bell (2013) sexism masih menjadi faktor utama yang paling kuat atas terjadinya rape culture di masyarakat, penekanan pada konstruksi gender melahirkan pandangan bahwa laki-laki dituntut untuk menjadi aktif dan wanita menjadi pasif, perempuan pasif artinya tidak boleh menolak ajakan seksual pria, sehingga perempuan yang diperkosa dianggap bersalah karena kuatnya pengaruh gender yang ada dalam masyarakat tersebut.

Dari hasil penelitian ini, meski konsisten bahwa sexism yang tinggi cenderung mempengaruhi secara positif pada penerimaan mitos pemerkosaan. Namun dari sisi jenis kelamin tanpak bahwa laki-laki lebih mempunyai penerimaan myth of rape dibanding perempuan. Pada penelitian kali ini selain sexism jika berusaha menjelaskan kaitan antara kemarahan moral dengan myth of rape, hasilnya menunjukkan tidak ada pengaruh kemarahan moral outrage dengan myth of rape.

Kekerasan seksual terhadap perempuan, khususnya dalam bentuk pemerkosaan, merupakan masalah serius yang harus ditangani di Indonesia. Para korban kekerasan seksual tidak diselimuti oleh atmosfer yang mendukung karena penerimaan yang luas dari mitos perkosaan di masyarakat (Poerwandari, Utami \& Primasari, 2019), bahkan di negara yang mempunyai peradaban lebih maju sekalipun (Kunst, Bailey, Prendergast \& Gundersen, (2019). Perkembangan ini diduga karena makin terpaparnya masyarakat dengan media-media yang menayangkan konten yang membuat pikiran masyarakat lebih permisif pada pemerkosaan, Seperti lelucon tentang pemerkosaan (Kavanagh, \& Brown, 2019).

Terdapat $70 \%$ perempuan sebagai korban pemerkosaan mengatakan bahwa ia mengalami reaksi sosial negatif yang disebabkan oleh mitos pemerkosaan. Mitos pemerkosaan merupakan kesalahpahaman tentang terjadinya pemerkosaan, perempuan dianggap berbohong atas peristiwa pemerkosaan, dan perempuan dianggap memancing perkosaan (Hayes 2013). Penelitian yang lain menunjukkan bahwa mitos pemerkosaan sebagai mediator terhadap kecenderungan seseorang untuk melakukan pemerkosaan atas dasar kekuasaan. Rape culture juga bergantung pada mitos pemerkosaan, gender, dan stereotip masyarakat (Davies, 2013). Penelitian oleh Stoll, Terry Glenn Lilley \& Kelly Pinter (2016) terkait dengan pencegahan kekerasan seksual di kampus. Individu yang memiliki bingkai kuat dengan sexism lebih mungkin untuk menerima rape culture.

Kelonggaran pada sebuah kejahatan khususnya pemerkosaan akan berdampak pada reaksi masyarakat pada pemerkosaan itu sendiri. Dengan kata lain masyarakat akan menjadi tidak sensitif pada kasus-kasus pemerkosaan. Pada penelitian ini tidak ditemukan adanya pengaruh moral outrage dengan myth of rape. Hal ini ini menjadi tantangan tersendiri pada penenganan kasus-kasus pemerkosaan. Hasil penelitian ini berbeda dengan penelitian sebelumnya, misalnya Chapleau, K. M \&. Oswald D L (2014), dalam penelitiannya menunjukkan bahwa moral outrage mempunyai pengaruh yang negatif pada myth of rape. Ada beberapa faktor yang diduga menjadi penyebab tidak berkorelasinya antara moral outrage dengan myth of rape, salah satunya adalah pengalaman subjek. Bagi individu yang pernah mengalami kejahatan atau berinteraksi dengan korban akan mempunyai merasakan efek emosi yang lebih dibanding dengan yang tidak pernah berinteraksi dengan korban atau menjadi korban (Darley \& Pittman, 2003). 
ESA LAILI \& FATHUL LUBABIN NUQUL, Luka Yang Terabaikan: Kajian Tentang Pengaruh Hostile Sexism Dan Kemarahan Moral Terhadap Mitos Pemerkosaan

Meskipun demikian kemarahan moral dibutuhkan untuk membangun empati pada korban dan kewaspadaan pada kasus pemerkosaan. Banyak kasus-kasus pemerkosaan atau yang lebih ringan seperti pelecehan seksual tidak terungkap karena kengganan korban melakukan pelaporan. Korban merasa khawatir bahwa laporan mereka tidak akan dipercaya atau karena mereka pikir petugas polisi tidak akan dapat membantu (Ocampo et al., 2007; Silber-Ashley \& Foshee, 2005). Keengganan korban mengungkapkan kasusnya karena berbagai pertimbangan selain karena keberhasilan penyelesaian kasus juga keselamatan diri korban (Trihastuti \& Nuqul, 2020). Toleransi masyarakat pada pemerkosaan, sepertinya yang dikatakan dipengaruhi oleh kemarahan moral masyarakat yang makin menipis pada kasuskasus.

\section{KESIMPULAN}

Penelitian ini membuktikan bahwa rape culture, hostile sexism dan moral outrage pada mahasiswa Universitas Islam Negeri Maulana Malik Ibrahim Malang berada dalam kategori sedang yaitu, rape culture sebesar 79,2\%, hostile sexism sebesar $73,1 \%$ dan moral outrage sebesar 50\%.Terdapat pengaruh yang signifikan hostile sexism dan moral outrage terhadap rape culture. Hal ini berdasarkan hasil uji regresi berganda antara hostile sexism dan moral outrage terhadap rape culture yang menunjukkan hasil $\mathrm{F}=86,108$ dengan tingkat signifikan $0,000(<0,05)$. Hasil analisis yang dilakukan secara bersama-sama, hostile sexism dan moral outrage mempengaruhi rape cultute sebesar 40,1\%. Secara terpisa, hostile sexism memberikan sumbangan sebesar 38\% dan moral outrage membeikan sumbangan sebesar $0,10 \%$ terhadap rape culture. Jadi, hostile sexism lebih memiliki pengaruh yang besar terhadap rape culture dibandingkan dengan moral outrage. Bagi peneliti selanjutnya, tentu dalam penelitian ini terdapat banyak kekurangan, terutama pada keterbatasan peneliti dalam mendeskripsikan hasil penelitian. Karenanya, diperlukan lebih lanjut guna memperdalam pemahaman mengenai rape culture, tentunya akan lebih baik jika dicoba dengan mengkombinasikan variabel lain seperti, feminist, sexual politict, dan gender.

\section{DAFTAR PUSTAKA}

Badan Pusat Statistika Jakarta Pusat. (2017). Preverensi Kekerasan Terhadap Perempuan Di Indonesia Hasil SPHPN 2016. Jakarta Pusat: Badan Pusat Statistika.

Beugre, C. D. (2012). Development and Validation of a Deontic Justice Scale. Journal of Applied Social Psychology,42(10). 1559-1816.

Bonnita, A., Sarwono, S. W., \& Novianti, A. (2006). Sumbangan Prasangka Gender Pada Sikap Bawahan Terhadap Manajer Perempuan. Jurnal Psikologi Sosial, 12(3). 169-180.

Buchwald, E., Fletcher, P., \& Roth, M. (2005). Transforming a Rape Culture. Mineapolis: Milkweed Editions.

Chapleau, K. M \&. Oswald D L (2014) A System Justification View of Sexual Violence: Legitimizing Gender Inequality and Reduced Moral Outrage Are Connected to Greater Rape Myth Acceptance, Journal of Trauma \& Dissociation, 15(2), 204218, DOI: $10.1080 / 15299732.2014 .867573$

Chapleau, K. M., Oswald, D. L., \& Russell, B. L. (2008). Male Rape Myths: The Role of Gender, Violence, and Sexism. Journal of Interpersonal Violence, 23(5), 600-615. https://doi.org/10.1177/0886260507313529

Darley, J. M. and Pittman, T. S. (2003). The psychology of compensatory and retributive justice. Personality and Social Psychology Review, 7: 324-336. doi:10.1207/S15327957PSPR0704_05 
Davies, M., Walker, J., \& Archer. P. P. (2013). The Scriping of Male and Female Rape. Journal of Aggresion, Confflict and Peace Research, 5(2). 68-76.

Dinillah, M. (2019). Mahasiswa UIN Bandung Tuntut Transparansi Investigasi Dosen Cabul. https://news.detik.com/berita-jawa-barat/d-4496445/mahasiswa-uin-bandung-tuntuttransparansi-investigasi-dosen-cabul. Diakses 20 Agustus 2019.

Dwiati, I. (2007). Perindungan Hukum Terhadap Korban Tindak Pidana Perkosaan Dalam Peradilan Pidana. Thesis. Semarang: Universitas Diponegoro.

Glick, P., \& Fiske, S. T. (1996). The Ambivalent Sexism Inventory: Differentiating hostile and benevolent sexism. Journal of Personality and Social Psychology, 70(3), 491512. https://doi.org/10.1037/0022-3514.70.3.491

Grubb, A., \& Turner, E. (2012). Attribution of blame in rape cases: A review of the impact of rape myth acceptance, gender role conformity and subtance use on victim blaming. Aggresion and Violance Behaviour, 17(5). 443-452.

Hayes, Rebbeca M., Lorens, Khaterine., Belle, K. A. (2013). Victim Blaming Others: Rape Myth Acceptance and The Just World Belief. Journal of Feminist Criminology, 8(3). 2002-220.

Herman, D. (1989) The Rape Culture, in Woman: A Feminist Perspective, Jo Freeman. Mountain View, CA: Mayfield.

Hermawati, I. (2018). Seksisme Dalam Lagu Bojoku Galak Via Valen. Tuah Talino. 12 (1): 113-122.

Jamaa, L. (2014). Perlindungan Korban Kekerasan Dalam Rumah Tangga Dalam Hukum Pidana Indonesia. Jurnal Citra Hukum, 2(2). 250-272.

Jonas R. Kunst, April Bailey, Claire Prendergast \& Aleksander Gundersen (2019) Sexism, rape myths and feminist identification explain gender differences in attitudes toward the \#metoo social media campaign in two countries, Media Psychology, 22:5, 818843, DOI: $10.1080 / 15213269.2018 .1532300$

Kavanagh E. \& Brown, L (2019) Towards a research agenda for examining online genderbased violence against women academics. Journal of Further and Higher Education 0:0, 1-9.

Krishnan, K. (2015).Rape Culture and Sexism in Globalising India. SUR Journal, 12(22). 255-259.

Kurniasari, N. T. (2011). Seksisme dan Seksualitas Dalam Lagu Pop: Kajian Terhadap Lirik Lagu Surti Tejo Menggunakan Analisis Tekstual. Pamator, 4(1). 31-39.

Lubis. (2013). Psikologi kesehatan reproduksi: Wanita \& perkembangan reproduksinya. Jakarta: Kencana Prenada Media Grup.

Mayer, M.C., Berchtold. I.M., Oestrich, F. (1987). Sexual Harassment. New York: Harper Collins.

Muehlenhard, C. L., \& MacNaughton, J.S. (1988), Women's Be Liefs About Women Who "Lead Men On". Journal of Social and Clinical Psychology, 7(1). 65-79.

Mullen, E., \& Skitka, 1. J. (2006). Exploring the Psychological Underpinnings of The Moral Mandate Effect: Motivated Reasoning Grup Differentiation, or Anger. Journal of Personality and Social Psychology, 90(10).629-643.

Ocampo, B. W., Shelley, G. A., \& Jaycox, L.H. (2007). Latino teens talk about help- seeking and help-giving in relation to dating violence. Violence Against Women, 13(2), 172189.

Payne, D.L., Kimberly, A.L., \& Louise, F.F. (1999). Rape Myth Acceptance: Exploration of Its Stucture and Its Measurement Using the Illinois Rape Myth Acceptance Scale. Journal of Research in Personality, 33.27-68.

Poerwandari, E.K., Utami, C.P. \& Primasari, I. (2019) Ambivalent sexism and sexual objectification of women as predictors of rape myth acceptance among male college 
ESA LAILI \& FATHUL LUBABIN NUQUL, Luka Yang Terabaikan: Kajian Tentang Pengaruh Hostile Sexism Dan Kemarahan Moral Terhadap Mitos Pemerkosaan

students in Greater Jakarta. Current Psychology. https://doi.org/10.1007/s12144-01900500-w

Posel, D. (2005). The Scandal of Manhood: 'Baby Rape' and the Politicization of Sexual Violence in Post-Apartheid South Africa. Culture, Health \& Sexuality, 7(3), 239-252.

Putri, D.M.A. (2012). Blaming The Victim: Representasi Perempuan Korban Pemerkosaan di Media Massa (Analisis Semiotika dalam Pemberitaan di Koran Suara Merdeka Desember 2011- Februari 2012). ejournal3.undip. 1-15.

Putsanra, D.V. (2019). Kasus Agni Bagaimana UGM Mengabaikan Kasus Kekerasan Seksual. https://tirto.id/kasus-agni-bagaimana-ugm-mengabaikan-kasus-kekerasanseksual-dgpM. Diakses 20 Agustus 2019.

Salama, N. (2013). Seksisme Dalam Sains. SAWWA.8(2): 311-322.

Silber-Ashley, O., \& Foshee, V. A. (2005). Adolescent help-seeking for dating violence: Prevalence, sociodemographic correlates, and sources of help. Journal of Adolescent Health, 36, 25-31.

Sills, S. (2016). Rape Culture and Social Media.Feminist Media Studies, 16(6). 935-951.

Stoll, L.C., Terry, G. L., \& Kelly, Pr. (2016). Gender Blinding Sexism and Rape Mythe Acceptance. Violane Against Women. 1(18). 1-18.

Trihastuti, A \& Nuqul, F.L. (2020) Menelaah pengambilan keputusan korban pelecehan seksual dalam melaporkan kasus pelecehan seksual Jurnal Personifikasi. 11(1); 1-15

Wakslak, C.J., Jost, J. T., Tylor, T. R., \& Chan. E. S. (2007). Moral Outrage Mediates The Dampening Effect of System Justification on Support For Redistributive Social Policies. Psychological Science, 18 (3). 267-274.

Zuhra, W.U.N (2019). Testimoni Kekerasan Seksual 174 Penyintasan 79 Kampus 29 Kota. https://tirto.id/testimoni-kekerasan-seksual-174-penyintas-79-kampus-29-kota-dmTW. Diakses 3 September 2019. 